\title{
Cyber Community Towards Society 5.0 AndThe Future Of Social Reality
}

\author{
$1{ }^{\text {st }}$ Burhan Bungin, $2^{\text {st }}$ Monika Teguh, $3^{\text {rd }}$ Muhammad Dafa \\ ${ }^{1,2,3}$ School of Communication Science and Media Businesses \\ Universitas Ciputra Surabaya \\ Surabaya, Indonesia \\ ${ }^{1}$ burhan.bungin@ ciputra.ac.id*, ${ }^{2}$ monika.teguh@ ciputra.ac.id*, ${ }^{3}$ muhammaddafa01@ student.ciputra.ac.id \\ *corresponding authors
}

\begin{abstract}
In cyber community towards the Society 5.0 era, the use of industrial technology 4.0, especially communication media technology plays an important role. The information era causes digital communication media technology to develop very rapidly and encourage the birth of digital media that have real time capabilities and create new media. Currently mass media institutions that are not innovative are experiencing a fall. Then the existence of the construction of reality is also increasingly obscured by the mixing of life in the real world with the virtual world. Therefore, the study wants to criticize the existence of reality in the midst of the development of communication technology that is so fast. This study uses the interview method in collecting data and analyzing it using the narrative method. The results of this study are that in society 5.0 and industrial technology 4.0, a pseudo social reality constructed by communication technology media causes mass media to die, social harmony is confused and even lost, and hoaxes are attacks on harmony.technological advances in industry 5.0 increase above $70 \%$
\end{abstract}

Keywords:social construction, mass media, cyber community, society 5.0

\section{INTRODUCTION}

Today's society continues to rejoice with the presence of new communication media, both in the form of hardware and application based. Especially in Indonesia, urban communities to people in rural areas, are welcoming this euphoria with various responses that sometimes make us take a deep breath. Communication media technology that is in the hands of the community is not only able to make users smart, but also makes them very brave to attack other people, destroy social order, and even violate the law in their society. Communication media technology is not the only media that plays war in Society 5.0, but at least it is the most dominant media in creating cybercommunity. When the industrial revolution 4.0 has reached its peak, inevitably, human society will enter cybercommunity through the replication of Avatar's life.

Fundamental to human social history, has developed in several stages of civilization that creates a long history of social life of human society. Starting from hunting culture, hunting society is marked with Society 1.0. They live by hunting and moving from one area to another according to the availability of protein resources. The next stage, the nomadic way of life was abandoned by humans in the era of Society 2.0. This is due to several things, among others, the depletion of world protein sources and the growing human population, then humans began to cultivate crops, we know this period as an agrarian society (Society 2.0 ). The next development is the agricultural community began to produce agricultural products not only for their own needs, but also produced and sold to other communities. Simultaneously, social interactions are becoming increasingly globalized and natural processing technology has begun to develop, allowing the community to develop into an industrial society (Society 3.0). Industry is developing towards efficiency, saving natural resources, therefore efficient technologies are developing towards the information industry that can save natural resources and society, we know this era as the era of the information society (Society 4.0).

In this era, humans live in the era of cyber community. The era of cybercommunity is an era where humans can move in two different worlds. The first is the real world that we live in every day and the second is the cyber world, which is a world created by communication technology so that they can be active in the cyber community as they are active in the real world. One of the weaknesses of cyber community is that humans become objects of technology, that humans are only passive actors in technology created by humans themselves. So that humans have the same degree as the technology they created. In the Society 5.0 era, society was driven by the rapid advancement of communication technology in the Industrial revolution 4.0, namely the generation of cloud-based internet storage machines. This "heavenly" technology causes human technological abilities to imitate God's way of storing mankind's "reward-evil file" until the Day of Judgment. These cloud machines cause humans to easily create Big Data.

Big Data is a term that describes a large volume of data, which is stored in cloud machines, both structured data and unstructured data. The three strengths of Big Data are the volume of data collected from various sources such as business transactions, social media and information on data search engines such as Google, Baidu, Bing, Yahoo, Naver, Ask, Dogpile, AOL and so on. In addition, Big Data has the speed of being created from RFID tags (smart sensors) so that it has real time capabilities. Most importantly Big Data has the ability to collect data in a variety of different formats so that it can be collected from different sources, ranging from structured, numerical data in traditional databases, text structured document data, email, video, audio, financial transactions, etc. In addition to the three important parts of Big Data, Big Data researchers also add important parts of Big Data, such as variability and complexity. The development of the Big Data engine has 
caused two other technologies to also develop in parallel, namely, Internet of Things (IoT) and Artificial Intelligence (AI). Big Data built through IoT will be converted into a new type of smart intelligence by AI. This ability will explore all corners of people's lives, especially people who have entered the cyber community.

IoT does not have a definite definition, because this concept is constantly evolving in every community activity. IoT is a concept where an object has the ability to transfer data over a network without requiring human-to-human or human-to-computer interaction. IoT is also evolving from the convergence of wireless technology, the internet and micro-electromechanical systems (MEMS). So that we can no longer identify a technology based on its initial nature and function, we can no longer even give it a definite name. Meanwhile AI is artificial intelligence designed on computers that emphasizes the creation of intelligent machines that work and react like humans, like recognition, learning, planning, problem solving, knowledge, thinking, perception, ability to manipulate and move objects. AI is designed to replace the role of humans in several social functions which will later be integrated in social systems in real life or cyber communities like what is currently being developed by several countries, such as Japan.

When we move to Society 5.0, all people's lives will be more comfortable and sustainable because people are only provided with products and services in the amount and time needed, so that reality is a non-material reality. The peculiarity of Society 5.0 is that pragmatism is the main goal in the practices of capitalism, where realism is becoming increasingly marginalized. The question is whether there is still a social reality in Society 5.0 when technology has taken over part or all of human life. Is there anything left of realism, especially when we repeat the question; Does reality still exist or is it gone?

Berger and Luckmann[1] explain that social reality is formed through social processes that occur in society. The social process occurs simultaneously through social processes; institutionalization, legitimacy, and socialization (ILS). The ILS social process is carried out through other simultaneous processes, namely externalization, objectification, and internalization (EOI). So that the social construction of reality is a simultaneous and multi-layered social process through ILS-EOI. In the process of institutionalization, there is the formation of patterns, rules, or roles among a group of people. The formation of this pattern is successful if the communication technology is deemed successful and relevant to meet the collective needs of the community in certain situations. So that roles and provisions are formed that make communication technology a structured institution in society. When technologies take over the role of humans, there has been a process of forming patterns, rules or the role of technology in the structure of human social life. For example, when robots replace receptionists, the role of humans in that field is lost and replaced by machines. When drones take over the position of transportation equipment that is fully operated by humans, human positions become unnecessary in that sector, even old transportation equipment loses its function. If the process of institutionalization of new technology is successful, then this structured technological institution is legitimized or justified with logical explanations, as a logical necessity, as a result of unavoidable change. Institutions are preserved by being socialized to new members of society. Starting from one technology is created, it has become a new member in the institution of society. Since then, it is considered to be able to create its social reality. It is socialized with his language institutions, family institutions, community institutions and others [2].

The process of creating social technology buildings (construction) takes place through 3 social processes in 3 other processes ( 3 in 3 ) simultaneously. The social building in question is a social reality that gives an image of a technological identity in social relations as well as the output of those social relationships. In the end, the social reality of technology gives identity to the outcome as an image attached to it. The description of the 3 in 3 process can be seen in Figure 1.

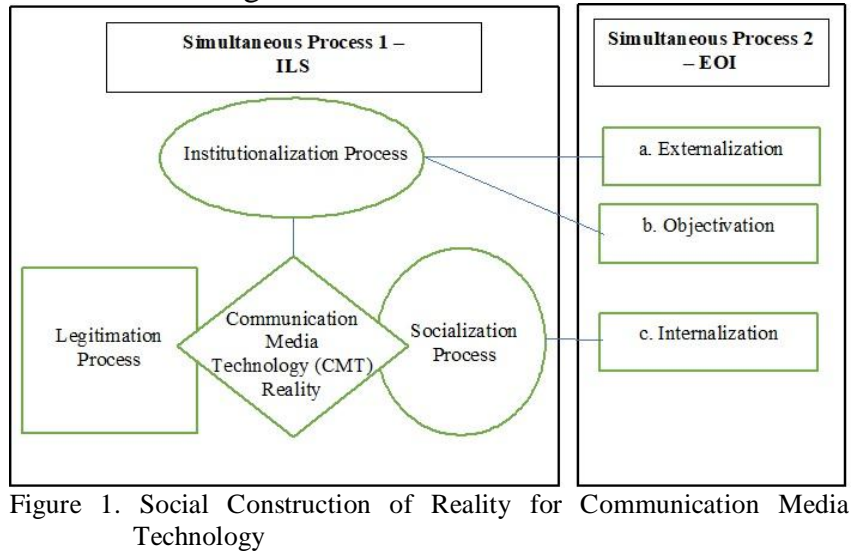

As seen in figure 1, there are two types of simultaneous processes that are actually connected to each other. The first process is ILS, which consists of Institutionalization, Legitimation and Socialization. At this stage of the Institutionalization process, there is the formation of patterns, rules, or roles between CMT and the community. The formation of this pattern is successful if the presence of CMT is felt to meet the collective needs of the community. Then at the next stage, institutionalization is legitimized or justified with logical explanations. Legitimacy can perpetuate or secure CMT-Society institutions. The CMT institution was then maintained through socialization to new members. The role of CMT is socialized with language institutions, family institutions, community institutions, and others. While the second process is EOI consisting of externalization, objectivation, and internalization. In relation to the first process, in this process it can be seen that the institutionalization of CMT occurs through externalization and objectivation. In the externalization stage, CMT undergoes a number of actions or roles that are repeated and enter into human logical consciousness and formulate them as social facts governed by certain rules. Then there is objectivation, where a CMT institution becomes an objective reality. After that, there was an internalization process when CMT became a community product. The internalization process transmits the CMT institution as an independent reality, especially to new 
members of society, so that the institution can be maintained over time. Including members of the community who conceptualize social institutions are also internalized so that the objectivation status of CMT institutions in their consciousness remains solid [3].

The social life of the community undergoes changes that never stop. The days are just a process of compiling a social construction that is increasingly shaping the image from the vague and abstract to a more concrete image building. From one social building to another, occurs naturally based on social laws. The social world is not a building without meaning, not empty spaces, not a process that is born and then disappears, but events created from very complex social interactions that will produce a reality, a momentum, and result in other social processes, and this happens continuously. A small reality that occurs today may reproduce a large social building event in the future. However, most of it is also a big social reality, will disappear with the passage of time in the future. The most important thing here is that events (reality) move according to social laws to create other events (reality) in the future [4]. Likewise, what is experienced by technological institutions in Society 5.0 is that the image of technology is constructed by its creator agent. Then it is born into the current reality and will disappear at another time following the direction in which the technological image is constructed. So that the reality of the technological image will come and go in its space and time.

Social reality, the world of social life, and reality are realities constructed by society. This is what ethnographers learn. They are not 'given' and they require detailed study that reflects and respects their complexity. The idea that social reality is socially constructed is commonplace. But it deserves careful attention. Constructionism (or constructivism) in general is a very important aspect of understanding ethnography. Unfortunately, it is easily misunderstood and poorly implemented. In particular, it is too easy to assume that a constructionist analytic perspective implies that phenomena are 'merely' constructed, or therefore have no material substance. But there is nothing trivial about the constructions, and they have real embodiments and practical achievements. Likewise, it is not the purpose of constructionist analysis simply to conclude that everything is social [5]. Therefore, this study will elaborate further on the construction of reality overshadowed by communication media technology in society 5.0.

\section{RESEARCH METHODS}

This research is based on the paradigm of postpositivism, with a simple research design method. The use of the post-positivism paradigm is what Creswell meant when he explained about combined research that this research combines a quantitative approach and a qualitative approach. The researcher begins the research deductively and finally the data is managed qualitatively. When Creswell describes the combined research method, Creswell uses the post-positivism paradigm of thinking as the basis for this method [6]. Burhan Bungin explains that a simple research design, which is very similar to the combined research method, is the most appropriate choice in research with a post-positivism paradigm. Thus, this study uses a post-positivism paradigm with a simple research design method. The researcher uses the steps of the simple research design method as follows: Social Context and Research Questions, Literature Review, Research Methods and Data Collection, Data Analysis, and Reporting [7].

In collecting data, the researcher interviewed 5 (five) informants as sources of information in this study, which were selected purposively, where the researcher had clearly recognized the capacity of the informants as data sources who had the ability to answer the researcher's questions. The informants consisted of 3 men and 2 women. Among the informants there are two communication media experts, two social media practitioners, and one communication media technology lecturer. Interviews were conducted around January 2021 to March 2021, held in several places in Surabaya, namely in cafes and in city parks, so as to create a calm condition and protect the privacy of informants and researchers. Thus, the research informants can express their questions and opinions clearly, without being penetrated by the environment and giving the impression of being forced. The results of the study were in the form of a diary, then a transcript of the interview was made. The study analyzed the interview transcripts manually using coding, categorization, themes and memos [8]. Finally, the researchers wrote the research results based on the results of the data analysis.

\section{III.RESULT AND ANALYSIS}

\subsection{Formation of Cyber Community}

As it is understood that a community is a group of people who occupy a certain territory for a relatively long time. Territoriality is the main characteristic of community that is not shared by other forms of shared life in human culture. Territoriality is not the only condition of the community, but also the social interaction of people who live together, the symbols and symbols they have, a social system based on legal norms that govern every behaviour of community member, ownership of stratification built on social classes in the community. In the community, independent communication manages their own lives so that awareness is created as part of the members of that communication.

The development of today's communication media technology on a massive scale in urban areas, makes this technology able to change human society into a society with new faces and characters. Able to transform local communities into global communities. Then it becomes a cyber community or avatar society, becoming a world that is transparent and able to adapt to the development of information, transportation and technology that is so fast and so big that it affects human civilization, such as "the big village", where the people are "each other". know" and "greet" with each other. The global community is also meant as a shared life where the people in it produce shared cultures and create a shared global market, which is very broad and without boundaries.

The development of communication media technology is also not only able to create a cyber community as a global world without boundaries and develop new life space for 
the community, so that without realizing it, the human community has lived in two worlds of avatar life, namely real community life and cyber community life. At first cyber community is a human fantasy about another world that is more advanced than the current world. The fantasy is a human hyper-reality about the value, image, and meaning of human life as a symbol of human liberation from the power of matter and the universe. But when human technology is able to reveal the mystery of that knowledge, then humans are able to create a new life space for humans in the hyper-reality world. As a human creation, the cyber community uses all methods of real community life as a model that is developed in aspects of virtual life. Such as, building social interaction and group life, building social stratification, building culture, building social institutions, building power, authority and leadership, building crime systems and social controls, and so on.

\subsection{Social Processes and Social Interactions}

Cyber community builds itself by fully relying on social interaction and social processes in group life (network) intra and between members of the cyber community. It is certain that the construction of cyber community initially developed from intra and inter-network systems that developed using a cobweb system to form a large community network. Social processes and social interactions in cybercommunity, some are temporary, and some are permanent for a relatively long time or permanently. The nature of these social processes and social interactions is determined by their importance in cyberspace. Temporary social interaction occurs when members of the public just want to "go for a walk" and only play in cyberspace through browsing and chatting, or search, then leave it. There is also social interaction and group life that lasts long enough among other members of the cyber community. They are Internet users (netters) who are in the cyber community all the time. They hang out, greet, make love, do business, study and even steal and so on in the cyber community, but they don't stay there because they don't have a home as their address [3]. Most of the members of the cybercommunity become permanent residents in the community by having addresses and houses there with the status of tenants or owners. These people have e-mail, websites, or even e-mail providers. Every time they use their addresses and homes to interact with fellow members of the cyber community for various needs.

As in real society, cyber community is built through computer-based social interaction through Adaptation of Human-Computer Interaction (HCI), with fellow members of the cyber community. Whereas the requirements for social interaction in real society must have social contact and communication, then these requirements are also the main substance in the social life of the cyber community. Relationships built in computer networks, not only have the meaning of relationships between electrical cable nodes or radio frequency nodes that can be received by one antenna or another but are actually social relationships built by community members to interact with each other, while the machines are just the media they use. Social contacts that occur between members of the cyber community have a broad meaning in their communication with each other, so that from there they are able to build meaning in an intersubjective world with one another [9].

From the way they interact, two processes of social interaction were born, namely the dissociative social process and the associative social process. The dissociative social process occurs when several members of the cybercommunity are involved in the process of competition, or even conflict with fellow citizens of the cybercommunity. This process occurs when they compete to provide access opportunities to the community and seek funding sources (sponsorship) to support their networks. For this they have to compete with other competitors who are also trying to do the same. This dissociative social process also occurs when a website network for various economic or political reasons is forced to attack other website networks, then they are involved in "war".

As the nature of networks and social processes in cyber communities that emphasize cooperation, in addition to dissociative social processes, most of these social processes are associative social processes between existing networks (groups). This process provides an opportunity for the virtual community, both intra and inter-network, to cooperate between them. This collaboration resulted in further processes such as the accommodation of information and the assimilation of cyber community culture on a global scale to the entire community network which ultimately influenced their behavior and interactions with one another.

\subsection{Cyber Social Group}

Virtual communities have complicated group life. Generally, these social groups are built based on secondary relationships, so that their grouping is based on the likes and needs of community members towards the group. There are two models of cyber social group membership. The first is called the intra group and the inter group. Intra group is a person's membership in intra group units centered on a particular server whose nature resembles a group of members in a particular institution. This intra group is usually referred to as an intranet, which autonomously regulates themselves, has internally agreed rules, has known greeting languages and has the ability to self-protect all interests, needs, and rules. what they want. Each member in this system must comply with the existing rules, both sanctions and rewards determined by their social system which is regulated in the existing server centers.

Although in general, this intranet relationship only applies internally, but actually these intranets are living cells in the wider social system of cyberspace, namely the Internet. In the Internet system, the largest group in the cyber community is a group whose membership is based on the needs of the host service (website) to guests which consists of two membership statuses, the first is free membership (free of charge) such as membership in e-mail services, chat, and certain websites, and secondly, membership remains based on members' status at a particular provider or website. Thus, the grouping of members in a cybercommunity occurs when certain information needs can be served by the website owner (host) as well as possible and as much as possible, 
especially when the information can be accessed easily and freely by the wider community. The larger the group (network) or the more people going back and forth through a network link, it is a measure that the network or website link has marketable public quality. That is, the website will bring in a lot of money for the owner. So it has an opportunity to develop the network (group) as wide as possible and as much as possible. Data on the websites with the highest traffic in Indonesia can be seen in figure 2, as an illustration of which websites have their own network in cyber communities in Indonesia.

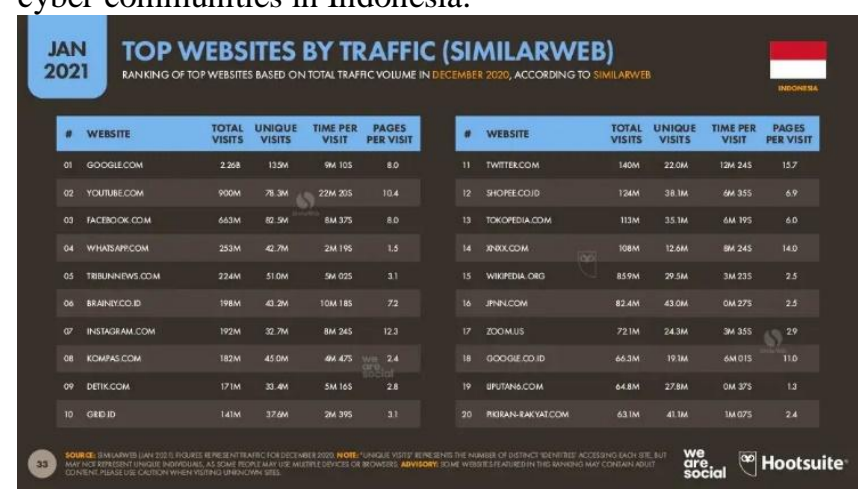

Figure 2. The Websites with The Highest Traffic in Indonesia

In addition to the two characteristics of social groups in the cyber community above, there are also other secondary characteristics of the cyber community. Those characteristics are temporary membership or trial and permanent membership. The characteristic of temporary membership is the privilege that is given to anyone who wants to join this social group and is temporary for free. Meanwhile, if a person wants to become a permanent member in a social group in the cyber community, he or she can become a permanent member for a certain period of time and is required to pay the specified group fee. This permanent membership is a privileged priority, with various facilities that are not available on temporary membership. Membership in cyber community social groups has the nature of clustering (crowd), crowding in certain networks, for various activities, such as accessing data, accessing information, just looking around (viewer), or just chatting, just saying hello (comment), updating status, or even just getting to know someone and then disappearing. In the business world, the most important and characteristic feature of membership in a cyber community is their existence in the group or network. That the presence of each member in a network group is calculated based on how much that member uses the space provided by the host (website owner) or marketplace. In real communities, the presence of individuals is not taken into account in this space, even though economic and social space is a serious consideration. Consideration of the space used by guests or members because the host himself has limited space. Although actually this virtual space (cyberspace) can be developed indefinitely by the creator of the technology itself.

\subsection{The Social Construction of Society $\mathbf{5 . 0}$}

The Industrial Revolution (4.0) is one number smaller than the development of the Society (5.0); this is because human society first existed and developed, then various technologies were born in that era. Technology was created by humans for the benefit of human society, therefore society first developed and then developed industry. In Society 5.0, various human roles are replaced by technology, such as the role of drones for logistics and transportation problems is more prominent, as well as household appliances will use artificial intelligence technology, the demand for medical care needs is getting higher by using robots. Smart work will also become a work model in various industries such as hotels, hospitals, households and so on, so that robots become human coworkers or assistants and even become "wives or husbands" in our homes. The wider use of cloud services will make it easier and more enjoyable for users in various business fields such as cloud accounting, production management, and sales management. New actors will come in logistics and transportation such as autonomous vehicles, like in scifi films, becoming a symbol technology of the future.

Our personal and professional lives are filled with digital data and information technology through which we develop and share ideas, which in turn generate new businesses. Imagine how our lives have changed over the last 10 years, with the advent of smartphones, new ways of shopping, new ways of working, and the like. If we have changed that much in ten years, then how far have we come over the last 50 years, or even the last 30 years? No one could have imagined that phenomenal change. Digital technology has brought us from an industrial society centred on manufacturing to a society where information is the king. In 2016, the Japanese government released the "2016 Comprehensive Strategy of Science, Technology and Innovation". The following year, they released the 2017 edition of their comprehensive strategy, in which they further described Society 5.0, as a model for communicating the Japanese government's vision of a future society. This model is the culmination of various discussions among experts from various fields based on research on the history of technology and social development.

Society 5.0 is a social construction that is built to image a life that combines the real world and the cyber world. Society 5.0 is a life where people live in cyber communities by utilizing the advantages of the internet, big data and artificial intelligence. While they also live in the real world together with other people. It is described thus to denote the new society created by the transformation led by scientific and technological innovation, after the hunter-gatherer society, the agricultural society, the industrial society, and the information society", as can be seen in Figure 3 [10]. 


\begin{tabular}{|c|c|c|c|c|c|}
\hline & Society 1.0 & $\sum$ Society 2.0 & $\sum$ Soc & $\sum s$ & $\sum s$ \\
\hline Society & Hunter-gatherer & Agrarian & Industrial & Information & Super smart \\
\hline 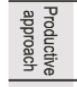 & Capture/Gather & Manufacture & Mechanization & ICT & $\begin{array}{c}\text { Merging of } \\
\text { cyberspace and } \\
\text { physical space }\end{array}$ \\
\hline Material & Stone $\cdot$ Soil & Metal & Plastic & Semiconductor & Material 5.0* \\
\hline ransport & Foot & Ox, horse & $\begin{array}{l}\text { Motor car, boat, } \\
\text { plane }\end{array}$ & Multimobility & $\begin{array}{c}\text { Autonomous } \\
\text { driving }\end{array}$ \\
\hline 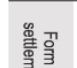 & $\begin{array}{c}\text { Nomadic, small } \\
\text { settlement }\end{array}$ & Fortified city & $\begin{array}{c}\text { Linear (industrial) } \\
\text { city }\end{array}$ & Network city & 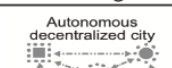 \\
\hline $\begin{array}{l}\text { City } \\
\text { ideals }\end{array}$ & Viability & ensiveness & Functionality & Profitability & Humanity \\
\hline
\end{tabular}

Figure 3. Characteristics of Society 1.0 to 5.0

Without understanding the underlying ideas, one cannot get a full picture of Society 5.0. What is the cyber world? What is the real world? What does it mean to combine these two spaces in a world called cybercommunity? What does it mean to balance economic progress with solving social problems? Readers would be forgiven for asking such a question. To find the answer, we must understand the thinking and narrative underlying Society 5.0. Peter Berger and Luckmann[1] are adherents of classical phenomenology, they see social processes take place in evolution. Information transformation in social processes takes place from person to person in a linear manner. Peter Berger and Luckmann did not even see that one day technology (communication) would take over the role of humans in social processes. Basic Social when Peter Berger and Luckmann made their thesis on the social construction of reality, was in the semi-modern era and was dominated by technology with characteristics of the Industrial 3.0 revolution era. The hallmark of American social relations in this era runs directly between people.

So what is really going on in this era of Society 5.0. If we look at what happened in the Industrial revolution 4.0, that in fact the main trend of this era is the merging of automation technology with cyber technology. So these cyber machines have grown in all aspects of life like mushrooms, covering all aspects of life related to important functions in people's lives, such as banking, education, state, transportation, social relations, science and so on. But there are also things that are not important, but entertaining and so on, for example FaceApp is one that is not important but becomes important when it becomes a trending topic on social media. Not only because FaceApp is an application that can change the reality of faces, but more than that, a reality can be created by these application machines by using existing resources in IoT, Big Data or AI. On the other hand, if we look at the output of these applications, let's say FaceApp, MSQRD, Face Swap Live, Snapchat, Pace Swap Booth, AgingBooth, Face Swap, MixBooth, Face Swap-Axhunter, Face Changer, Face Switch, Face Changer Video, Multi Face Blender, Change Face, Face Swap-Wombatica Software, Face Swap Live-Android, is something that actually removes reality, or even makes reality something that these machines create.

The question is, does reality actually still exist? Or it has disappeared in the sense that reality actually exists solely because it was created by humans, outside of that there really is no reality. Durkheim said that social reality is something that is material or observable and also something that is not material or observable. But both these realities exist in observation as well as in consciousness. In other words, social reality is a reality that physically exists and there is also a conscious awareness [11]. The reality is that society 5.0 uses technology that is able to change the reality of the image to be in consciousness but not physically. The applications mentioned above are able to turn objects into real imagery that are not real (non-existent) but can be observed as a real image reality. Social reality, which Berger and Luckmann said is a product of social construction, is the result of a complex social process in simultaneous social processes, which becomes very simple in society 5.0, because the social construction process has been replaced by the image construction of applicationsapplications made by internet-social media machines, make the process of social construction of social reality very quickly built, quickly exists, then does not exist and then is meaningless. This is the future of social reality in the era of society 5.0, as something that exists and is created by internet-social media machines.

\section{CONCLUSION}

The IoT engine, Big Data and AI is the industrial revolution 4.0 and is the beginning of society 5.0. Technological substances as human equipment has periodically been more efficient and more sophisticated in serving humans. The presence of technology in society 5.0 makes human life more meaningful because of its own creation. But behind all that there are other social processes that are missing, which have been created in a long, simultaneous, and convoluted social process, namely the social reality that has been an important part of human social life. Social reality is not only something that is visible but also something that exists in social life.

In fact, that various social realities in society 5.0 such as society, social interaction, status and roles, values and norms, social institutions, culture, social stratification, social behaviour, and social change are human social realities created through the process of social construction, will disappear one by one, at least will change slowly. These changes occur because the roles of internet and social media application engines have dominated and replaced the mainstream forces in the social construction process as stated by Berger and Luckmann. These social realities will change or even disappear from human life. Let's say, social changes in the family, because household robots will replace human life partners, this will make the social reality of the family shift or disappear. The human population will decrease due to this new social reality, and one day 
humanity will perish. Social groups will disappear replaced with virtual groups on Facebook or WhatsApp and so on. The loss of various old social values and replaced with social values based on the laws of social media. Changes in social behaviour of people using social media who forget their surroundings, changing social stratification based on likes not because of knowledge, wealth, and honour and so on and so on.

These changes will bring the old human social reality lost in society 5.0 and will be replaced with a new reality, or even completely irreplaceable in other words destroyed. So, what Japan really thinks is not something wrong but also not something right in the old social order, but all of it is a hedonism effort that is fueled by the enjoyment of living more comfortably with self-invented technology. The end of all this is the victory of capitalism, that these big technology-making companies will reap huge profits from the creation of those technologies in a cycle that places humans as slaves to technology and slaves to capitalism. technological advances in industry 5.0 increase above $70 \%$

\section{THANK-YOU NOTE}

The researchers would like to thank all the informants and the committee from ICOEN who have helped to make this manuscript possible.We would also like to acknowledge funding from the School of Communication Science and Media Businesses for this research.

\section{REFERENCES}

[1] P. L. Berger and T. Luckmann, The Social Construction of Reality. London: Penguin Books, 1991.

[2] G. Riyanto, Peter L. Berger: Perspektif Metateori Pemikiran. Jakarta: LP3ES, 2009.

[3] B. Bungin, Sosiologi Komunikasi:Teori, Paradigma, dan Diskursus Teknologi Komunikasi di Masyarakat. Jakarta: Kencana, 2017.

[4] B. Bungin, Komunikasi Politik Pencitraan: The Social Construction of Public Administration (SCoPA). Jakarta: Prenada Media, 2018.

[5] J. D. Atkinson, "Journey into Social Activism: Qualitative Approaches," Eur. J. Commun., vol. 32, no. 6, p. 631, 2017, doi: https://doi.org/10.1177/0267323117739171g.

[6] J. W. Creswell and J. D. Creswell, Research Design Qualitative, Quantitative, and Mixed Methods Approaches, 5th ed. California: SAGE Publications, Inc., 2018.

[7] B. Bungin, POST-QUALITATIVE SOCIAL RESEARCH METHODS: Kuantitatif-Kualitatif-Mix Methods Positivism-PostpositivismPhenomenology-Postmodern Filsafat, Paradigma, Teori, Metode dan Laporan. Jakarta: Kencana, 2020.

[8] J. Saldana, The Coding Manual for Qualitative Researchers. Arizona: SAGE Publications Ltd, 2015.
[9] W. V. Siricharoen, "Understanding Social Interaction with Human Computer Interaction (HCI) Adaptation," EAI Endorsed Trans. Context. Syst. Appl., vol. 6, no. 18, pp. 1-9, 2019, doi: 10.4108/eai.13-7-2018.160762.

[10] Hitachi-UTokyo Laboratory, Society 5.0: A Peoplecentric Super-smart Society. Singapore: Springer Nature, 2020.

[11] G. Ritzer and J. N. Stepnisky, Sociological Theory, 11th ed. California: SAGE Publications, Inc., 2021.

[12] Dwiyana, D., \& Muqorobin, M. (2021). Analysis of Adi Soemarmo Solo Airport Parking Payment System. International Journal of Computer and Information System (IJCIS), 2(1), 1-3.

[13] Jannah, A. M., Muqorobin, M., \& Widiyanto, W. W. (2020). Analysis Of Kids Garden Dapodic Application System. International Journal of Computer and Information System (IJCIS), 1(3), 55-58.

[14] Nur, U. C., \& Muqorobin, M. (2020). Development Of Smart Working Assistance Application For J\&T Express Couriers In Juwiring Klaten Branch. International Journal of Computer and Information System (IJCIS), 1(3), 52-54.

[15] Muqorobin, M., Utomo, P. B., Nafi'Uddin, M., \& Kusrini, K. (2019). Implementasi Metode Certainty Factor pada Sistem Pakar Diagnosa Penyakit Ayam Berbasis Android. Creative Information Technology Journal, 5(3), 185-195. 